Notes

1John McPeck, "The Evaluation of Critical Thinking Programs: Dangers and Dogmas," Informal Logic, 6:2 (July), 1984:9-13.

2Ibid., p. 11

3 Ibid., p. 10

4 lbid., p. 11.

5 For an analysis of causal hypotheses and a discussion of these examples, see Ronald N. Giere, Understanding Scientific Reasoning (N.Y.: Holt, Rinehart and Winston, 1979), Ch. 12.

6 David Annis, Linda Annis," "Does Philosophy Improve Critical Thinking?," Teaching Philosophy, 3:2 (Fall), 1979:145-152.
7It should be noted, however, that it is not exactly clear what it means to say that philosophy is intrinsically valuable or whether the statement is true. See, e.g., William Frankena's discussion of intrinsic value in his Ethics, 2nd ed. (Englewood, N.J .: Prentice-Hall, 1973) Ch.5.

8 We wish to thank Professor Arnold Wilson, the Editor of Teaching Philosophy, for making us aware of McPeck's article. Professor Wilson attended the Second International Symposium on Informal Logic Held at the University of Windsor in June 1983 when McPeck presented his paper. $\square$

Dr. David B. Annis and Dr. Linda F. Annis, Department of Philosphy, Ball State University, Muncie, IN 47306.

\title{
note
}

\section{Informal Logic in China}

\author{
John Nolt
}

\section{University of Tennessee}

There is, in The People's Republic of China, great potential for interest in and development of informal logic. That is my impression from recent discussions with students and faculty members at Nanjing Institute of Technology. I had gone to China primarily as a tourist, but from July 20 to July 24, 1984, I was a guest at the Institute, where I gave a talk outlining the development in informal logic in the U.S. and Canada.
I had not known what to expect, having relatively little information on the status of logic in China. I hoped to learn at least as much as I had to tell. What I found was an electrifying cosmopolitanism among the young and a lingering dogmatism among the older generation.

Before the communist victory in 1949, China harbored a large school of Vienna-style logical pos- 
itivists, who were well acquainted with formal logic as a tool of mathematical and philosophical analysis. But in the years following 1949, formal logic disappeared from Chinese universities as "decadent" Western influences were eliminated. In place of logic, Chinese curriculums now offered Marxist dialects, much of it imported directly from the Soviet Union.

During the late $50^{\prime} s$ and $60^{\prime} s$, formal logic began slowly to reappear, primarily in teachers' colleges as an adjunct to rhetoric and in departments of mathematics. It played little role in the development of philosophy, which remained wedded to orthodox Marxism.

The Cultural Revolution suppressed intellectual activity of all kinds during the late $60^{\prime}$ s and early $70^{\prime} \mathrm{s}$. But developments since the overthrow of the Gang of Four in 1977 have been remarkable. In these seven years the intellectual climate of China has shifted from fearful caution to spirited optimism, curiousity and enthusiasm. A great deal of catching up has been done very quickly.

Formal logic has begun to play a prominent role once again; but this time interest is centered mainly in its computer applications. It is taught primarily in mathematics departments and seldom as a philosophical discipline. Philosophy as such remains predominantly Marxist. Still, the philosophers I talked with were surprisingly well-informed about recent Western developments. After my talk, for example, I was asked detailed questions about the relation of informal logic to fuzzy logic and to Montague grammar.

No one I met, however, had yet heard of informal logic. Reactions varied-again depending on age. The older generation seemed to want to classify it or identify it with something familiar. Since my particular brand of informal logic uses an intuitive possible worlds semantics, one senior philosopher insisted on identifying it with Carnapian semantics. I had difficulty explaining to him that informal logic was something quite different in scope and aim. There was curiousity among the older generation, but I did not sense enthusiasm.

Among the young, however, enthusiasm was intense-particularly in private discussions. In my public lecture, I emphasized the practicality of informal logic, but not its role, say, in criticizing the arguments of public officials of unearthing dogmatic assumptions. These topics, I thought, might be too sensitive. Yet they were precisely what appealed most to the younger intellectuals. One young man grew very excited when I explained (in private) how informal logic is used to encourage students to make explicit and critically examine habitual assumptions and modes of inference. "This," he said, "is just what we need to loosen up people's thinking."
The young people I talked with expressed little fear of recrimination for political criticism and talked freely about the mistakes of Chairman Mao and even of current political leaders. They seemed confident that this new freedom of expression has solid popular support and will not be rescinded in the near future. If this optimism proves justified, and if the excitement evident in Nanjing is typical, then there is great potential for the teaching and development of informal logic in Chinese universities. (There will be no dearth of material for analysis; the most frequently used pattern of argument in popular Chinese publications seems to be appeal to authority.)

After my talk, I was asked to send back issues of Informal Logic and the Informal Logic Newsletter and notices of upcoming conferences in informal logic to N.I.T. so that Chinese philosophers might have a chance to participate. If the Chinese do enter the field of informal logic, they will undoubtedly bring with them new ideas which will enrich our discipline substantially.

John Nolt, Department of Philosophy, University of Tennessee, Room 801 McClung Tower, Knoxville, Tennessee, 37996 